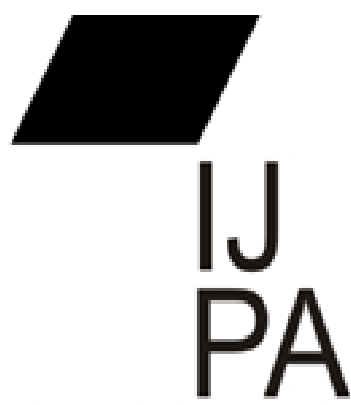

ISSN $2460=0369$

\section{ANALISIS FAKTOR-FAKTOR YANG MEMPENGARUHI PRODUKTIVITAS PUBLIKASI ILMIAH GURU PNS DI SMP NEGERI 1 REMBANG DAN SMP NEGERI 3 PENGADEGAN KABUPATEN PURBALINGGA}

\author{
Mugi Lestari, Muslih Faozanudin, Dyah Retna Puspita \\ Program Pascasarjana Ilmu Administrasi \\ Universitas Jenderal Soedirman \\ mugielestarie@gmail.com
}

\begin{abstract}
Generally, the productivity of scientific publication of civil servant teachers in Purbalingga District and especially in Kecamatan Rembang and Pengadegan is still low. Based on the results of previous research and expert opinion, the low productivity of teachers' scientific publications is caused by teacher motivation factors, teacher competence, teacher work load and social support. The purpose of this study to determine the magnitude of the influence of teacher motivation, teacher competence, teacher workload, and social support to the productivity of scientific publications of civil servant teachers in SMP Negeri 1 Rembang and SMP Negeri 3 Pengadegan Purbalingga District. This research method used quantitative research method of descriptive case study format. Research location in SMP Negeri 1 Rembang and SMP Negeri 3 Pengadegan Purbalingga District. The sampling technique used is saturated or census sampling where the research population is at once a sample. The results of this study indicate that there is a significant effect of teacher motivation factors, teacher competence, teacher workload and social support to the productivity of scientific publications of civil servant teachers in SMP Negeri 1 Rembang and SMP Negeri 3 Pengadegan Purbalingga District, either independently or simultaneously. The influence of teacher motivation is $48,6 \%$ with positive direction, teacher competence $33,9 \%$ with positive direction, teacher work load $28,4 \%$ with negative direction, and social support equal to $34,3 \%$ with positive direction. On the other hand, the influence of teacher motivation, teacher competence, teacher work load, and social support simultaneously to the productivity of scientific publication of civil servant teachers in SMP Negeri 1 Rembang and SMP Negeri 3 Pengadegan Purbalingga District is $53.1 \%$. That is, as much as $46.9 \%$ productivity scientific publications teachers influenced by other factors outside this study.
\end{abstract}

Keywords: Productivity of teachers' scientific publications, teacher motivation, teacher competence, teacher workload, social support. 
Abstrak: Secara umum, produktivitas publikasi ilmiah guru PNS di Kabupaten Purbalingga dan khususnya di Kecamatan Rembang dan Pengadegan masih rendah. Berdasarkan hasil penelitian terdahulu dan pendapat para ahli, rendahnya produktivitas publikasi ilmiah guru PNS antara lain disebabkan oleh faktor motivasi guru, kompetensi guru, beban kerja guru dan dukungan sosial. Tujuan penelitian ini untuk mengetahui besarnya pengaruh motivasi guru, kompetensi guru, beban kerja guru, dan dukungan sosial terhadap produktivitas publikasi ilmiah guru PNS di SMP Negeri 1 Rembang dan SMP Negeri 3 Pengadegan Kabupaten Purbalingga. Metode penelitian ini menggunakan metode penelitian kuantitatif format deskriptif studi kasus. Lokasi penelitian di SMP Negeri 1 Rembang dan SMP Negeri 3 Pengadegan Kabupaten Purbalingga. Teknik sampling yang digunakan adalah sampling jenuh atau sensus dimana populasi penelitian sekaligus menjadi sampel. Hasil penelitian ini menunjukkan bahwa terdapat pengaruh yang signifikan faktor motivasi guru, kompetensi guru, beban kerja guru dan dukungan sosial terhadap produktivitas publikasi ilmiah guru PNS di SMP Negeri 1 Rembang dan SMP Negeri 3 Pengadegan Kabupaten Purbalingga, baik secara mandiri maupun secara simultan/bersama-sama. Besarnya pengaruh motivasi guru secara mandiri sebesar 48,6\% dengan arah positif, kompetensi guru sebesar 33,9\% dengan arah positif, beban kerja guru sebesar 28,4\% dengan arah negatif, dan dukungan sosial sebesar 34,3\% dengan arah positif. Di sisi lain, besarnya pengaruh motivasi guru, kompetensi guru, beban kerja guru, dan dukungan sosial secara bersama-sama/simultan terhadap produktivitas publikasi ilmiah guru PNS di SMP Negeri 1 Rembang dan SMP Negeri 3 Pengadegan Kabupaten Purbalingga adalah 53,1\%. Artinya, sebesar 46,9\% produktivitas publikasi ilmiah guru dipengaruhi oleh faktor lain di luar penelitian ini.

Kata Kunci: Produktivitas publikasi ilmiah guru, motivasi guru, kompetensi guru, beban kerja guru, dukungan sosial. 


\section{PENDAHULUAN}

Perkembangan ilmu pengetahuan tidak terlepas dari peranan publikasi ilmiah. Begitu juga untuk di Indonesia, publikasi ilmiah menjadi hal yang tidak kalah pentingnya dalam rangka ikut serta mengembangkan ilmu pengetahuan tersebut. Namun, dalam pelaksanaannya ternyata kegiatan publikasi ilmiah tidak semulus yang diharapkan. Hal ini dikarenakan masih sangat minimnya minat dan motivasi bangsa Indonesia untuk melaksanakan penelitian.

Jumlah publikasi ilmiah Indonesia masih tertinggal dibandingkan dengan negara lain di Asia, khususnya dengan Jepang, China, Korea Selatan, dan India (Kompas.com, 2013). Berdasarkan data Pusat Penelitian Perkembangan Iptek Lembaga Ilmu Pengetahuan Indonesia, dalam kurun waktu 2001-2010, lembaga penelitian dan pengembangan di Korea Selatan, KAIST, menghasilkan jumlah publikasi internasional terbesar, yaitu 20.183 publikasi. Lalu, diikuti lembaga JST Jepang (13.604) dan CSIRO Australia (11.611) dan LIPI memiliki 417 publikasi ilmiah (Pappiptek-LIPI). Jumlah publikasi itu bahkan juga lebih rendah dibandingkan dengan negara ASEAN, seperti Singapura, Thailand, dan Malaysia. Selama kurun waktu yang sama, total publikasi nasional dan internasional dari tiga negara tetangga tersebut di atas 30.000, sedangkan Indonesia hanya menghasilkan total publikasi 7.843 .

Sebagai salah satu komponen bangsa, guru menjadi pemandu dalam perkembangan ilmu pengetahuan secara umum. Oleh karenanya, guru juga tidak luput dari imbas dalam tuntutan pembuatan publikasi ilmiah. Hal itu sesuai dengan apa yang diatur dalam PermenPAN dan RB No. 16 Tahun 2009 tentang jabatan fungsional guru dan angka kreditnya yang menjelaskan bahwa salah satu kegiatan pengembangan profesi guru adalah publikasi ilmiah. Pada pasal 16 ayat 2 PermenPAN dan RB tersebut menyebutkan bahwa untuk kenaikan jabatan/pangkat setingkat lebih tinggi dari Guru Pertama, pangkat Penata Muda, golongan ruang III/a sampai dengan Guru Utama, pangkat Pembina Utama, golongan ruang IV/e wajib melakukan kegiatan Pengembangan Keprofesian Berkelanjutan (PKB) yang meliputi subunsur pengembangan diri, publikasi ilmiah, dan/atau karya inovatif. 
Hal tersebut juga didukung data yang menjelaskan bahwa ada sekitar 800.000 guru yang stagnan di IV/a karena tidak bisa membuat karya tulis ilmiah. Guru SD, sebanyak 30,4\% guru terhenti di golongan IV/a. Di SMP, guru golongan IV/a sebanyak 28,3\%. Hanya sedikit yang bisa ke golongan IV/b ke atas, bahkan tidak ada guru SD dan SMP yang bisa ke IV/e (Kompas.com, 2014).

Di Kabupaten Purbalingga keadaannya juga tidak jauh berbeda. Banyak guru SMP yang terhenti digolongan IV/a dimana prosentasenya paling besar dibanding golongan yang lain. Hal tersebut bisa dilihat dari data BKD Kabupaten Purbalingga tahun 2015 sebagai berikut:

Tabel 1. Jumlah Guru PNS SMP Negeri Kabupaten Purbalingga

\begin{tabular}{|l|l|c|c|c|c|c|c|c|c|c|}
\hline \multirow{2}{*}{ No. } & & \multicolumn{4}{|c|}{ Golongan III } & \multicolumn{3}{c|}{ Golongan IV } & Total \\
\cline { 3 - 10 } & & $\mathrm{a}$ & $\mathrm{B}$ & $\mathrm{c}$ & $\mathrm{d}$ & $\mathrm{a}$ & $\mathrm{B}$ & $\mathrm{c}$ & $\mathrm{d}$ & \\
\hline 1. & $\begin{array}{l}\text { Jumlah Guru PNS } \\
\text { SMP Negeri }\end{array}$ & 13 & 189 & 230 & 84 & 653 & 4 & 1 & - & 1174 \\
\hline 2. & Prosentase (\%) & $\begin{array}{c}1,11 \\
\%\end{array}$ & $\begin{array}{c}16,10 \\
\%\end{array}$ & $\begin{array}{c}19,5 \\
9 \%\end{array}$ & $\begin{array}{c}7,16 \\
\%\end{array}$ & $\begin{array}{c}55,62 \\
\%\end{array}$ & $\begin{array}{c}0,34 \\
\%\end{array}$ & $\begin{array}{c}0,09 \\
\%\end{array}$ & & \\
\hline
\end{tabular}

Sumber: Data sekunder diolah tahun 2015

Dari data tersebut dapat diketahui bahwa jumlah guru PNS SMP Negeri Kabupaten Purbalingga yang ada di golongan IV/a menempati jumlah tertinggi yaitu 653 dibandingkan golongan yang lain apalagi kalau dibandingkan dengan golongan IV/a ke atas. Hal itu menunjukkan bahwa guru PNS SMP Negeri di Kabupaten Purbalingga mayoritas terhenti di golongan IV/a dengan asumsi bahwa mereka kesulitan naik pangkat karena terganjal aturan adanya kewajiban melaksanakan publikasi ilmiah sebagai salah satu komponen Pengembangan Keprofesionalan Berkelanjutan (PKB). Selain itu, di Kabupaten Purbalingga, jumlah guru yang melaksanakan publikasi ilmiah dalam rangka kenaikan pangkat sebagai komponen PKB untuk periode 2016 tercatat 35 guru SMP (Dinas Pendidikan Kabupaten Purbalingga, 2016).

Observasi awal peneliti di Kecamatan Rembang dan Pengadegan Kabupaten Purbalingga, juga memiliki kondisi produktivitas publikasi ilmiah guru yang sama. Berdasarkan profil guru PNS, di antara sekolah-sekolah tersebut 
banyak guru yang terhenti di golongan IV/a. Berikut tabel profil guru PNS SMP Negeri berdasarkan golongan di Kecamatan Rembang dan Pengadegan:

Tabel 2. Profil Guru PNS SMP Negeri Berdasarkan Golongan di Kecamatan Rembang

\begin{tabular}{|l|l|c|c|c|c|c|c|c|c|c|}
\hline \multirow{2}{*}{ No Unit Kerja } & \multicolumn{9}{|c|}{ Gol III } & \multicolumn{5}{c|}{ Gol IV } & \multirow{2}{*}{ Total } \\
\cline { 3 - 9 } & & $\mathrm{a}$ & $\mathrm{b}$ & $\mathrm{c}$ & $\mathrm{d}$ & $\mathrm{a}$ & $\mathrm{b}$ & $\mathrm{C}$ & $\mathrm{d}$ & \\
\hline 1 & SMP N 1 Rembang & & 4 & 7 & 3 & 15 & & & & 29 \\
\hline 2 & SMP N 2 Rembang & & 5 & 7 & 6 & 4 & & & & 22 \\
\hline 3 & SMP N 3 Rembang & & 2 & 2 & & & & & & 4 \\
\hline 4 & SMP N 4 Rembang & & 3 & & & 1 & & & & 4 \\
\hline 5 & SMP N 5 Rembang & & - & - & - & - & & & & - \\
\hline 6 & SMP N 6 Rembang & & - & - & - & - & & & & - \\
\hline & Total & & 14 & 16 & 9 & 20 & & & & 59 \\
\hline
\end{tabular}

Sumber: Data skunder diolah tahun 2015

Tabel 3. Profil Guru PNS SMP Negeri Berdasarkan Golongan di Kecamatan Pengadegan

\begin{tabular}{|c|c|c|c|c|c|c|c|c|c|c|}
\hline \multirow[t]{2}{*}{ No } & \multirow[t]{2}{*}{ Unit Kerja } & \multicolumn{4}{|c|}{ Gol III } & \multicolumn{4}{|c|}{ Gol IV } & \multirow[t]{2}{*}{ Total } \\
\hline & & $\mathrm{a}$ & $\mathrm{b}$ & $\mathrm{c}$ & $\mathrm{d}$ & $\mathrm{a}$ & $\mathrm{b}$ & $\mathrm{C}$ & $\mathrm{d}$ & \\
\hline 1 & SMP N 1 Pengadegan & & 3 & 10 & & 10 & & & & 23 \\
\hline 2 & SMP N 2 Pengadegan & & 1 & 6 & 2 & 2 & & & & 11 \\
\hline 3 & SMP N 3 Pengadegan & & 3 & 4 & 1 & 2 & & & & 10 \\
\hline & Total & & 7 & 20 & 3 & 14 & & & & 44 \\
\hline
\end{tabular}

Sumber: Data sekunder diolah tahun 2015

Berdasarkan tabel tersebut, terlihat bahwa di Kecamatan Rembang total guru golongan IVa mencapai angka tertinggi yaitu 20 orang, disusul golongan IIIb, IIIc dan terendah IIId. Sedangkan di Kecamatan Pengadegan juga tidak jauh berbeda, meskipun jumlah golongan IVa bukan yang tertinggi (14 orang), namun tetap menunjukkan angka yang tinggi. Perlu diketahui pula bahwa mereka berada pada golongan IVa sudah cukup lama bahkan ada yang puluhan tahun. Selain itu, aturan membuat publikasi ilmiah juga diwajibkan untuk kenaikan golongan IIIb ke golongan yang lebih tinggi.

Hal tersebut juga dapat diasumsikan bahwa guru PNS SMP Negeri di Kecamatan Rembang dan Pengadegan mengalami kesulitan untuk naik pangkat karena terganjal aturan adanya kewajiban melaksanakan publikasi ilmiah sebagai salah satu komponen Pengembangan Keprofesionalan Berkelanjutan (PKB). Oleh karenanya, produktivitas publikasi ilmiah guru PNS SMP Negeri di Kecamatan Rembang dan Pengadegan kategorinya rendah. Sehubungan dengan hal tersebut, menarik untuk dikaji "Seberapa besar pengaruh motivasi guru, kompetensi guru, 
beban kerja guru, dan dukungan sosial baik secara mandiri maupun secara simultan terhadap produktivitas publikasi ilmiah guru PNS di SMP Negeri 1 Rembang dan SMP Negeri 3 Pengadegan Kabupaten Purbalingga?" tujuan penelitian untuk mengetahui seberapa besar pengaruh motivasi guru, kompetensi guru, beban kerja guru, dan dukungan sosial baik secara mandiri maupun secara simultan terhadap produktivitas publikasi ilmiah guru PNS di SMP Negeri 1 Rembang dan SMP Negeri 3 Pengadegan Kabupaten Purbalingga.

\section{TINJAUAN PUSTAKA}

\section{Produktivitas Publikasi Ilmiah Guru}

Ditinjau dari dimensi keorganisasian, konsep produktivitas secara keseluruhan merupakan dimensi lain dari pada upaya mencapai kualitas dan kuantitas suatu proses kegiatan berkenaan dengan bahasan ilmu ekonomi. Oleh karena itu, selalu berorientasi kepada bagaimana berpikir dan bertindak untuk mendayagunakan sumber masukan agar mendapat keluaran yang optimum. Dengan demikian konsep produktivitas dalam pandangan ini selalu ditempatkan pada kerangka hubungan teknis antara masukan (input) dan keluaran (output) (Kusnendi, 2003: 84).

Publikasi ilmiah guru adalah karya tulis ilmiah yang telah dipublikasikan kepada masyarakat sebagai bentuk kontribusi guru terhadap peningkatan kualitas proses pembelajaran di sekolah dan pengembangan dunia pendidikan secara umum. Publikasi ilmiah mencakup 3 kelompok kegiatan, yaitu: 1) Presentasi pada forum ilmiah; 2) Publikasi ilmiah hasil penelitian atau gagasan inovatif pada bidang pendidikan formal; 3) Publikasi buku teks pelajaran, buku pengayaan dan/atau pedoman guru (Kemendiknas, 2010). Dengan demikian dapat dikatakan bahwa produktivitas publikasi ilmiah guru merupakan kuantitas/jumlah dan kualitas karya tulis ilmiah yang telah dipublikasikan kepada masyarakat sebagai bentuk kontribusi guru terhadap peningkatan kualitas proses pembelajaran di sekolah dan pengembangan dunia pendidikan secara umum.

\section{Motivasi Guru}


Menurut Stenberg (2003), motivasi adalah kekuatan yang mendorong, menimbulkan dan mengarahkan perilaku. Pendapat lain mengatakan bahwa motivasi yang muncul dari faktor-faktor seperti minat, atau kuriositas dinamakan motivasi intrinsik, sedangkan motivasi yang timbul dari keinginan untuk mendapatkan pujian atau hadiah dan menghindari hukuman dinamakan motivasi ekstrinsik (Woolfolk, 1993:337). Sedangkan Santrock (2008) menyatakan bahwa motivasi adalah proses yang memberi semangat, arah dan kegigihan perilaku.

Jadi, berdasarkan pendapat para ahli tersebut, dapat disimpulkan bahwa motivasi guru merupakan pendorong baik dari dalam diri seseorang guru (motivasi intrinsik) maupun dari luar diri seseorang guru (motivasi ekstrinsik) yang dapat menimbulkan kegigihan perilaku guna melakukan sesuatu dan mengarahkan tindakan pada suatu tujuan yang ingin dicapai.

\section{Kompetensi Guru}

Kompetensi guru adalah kemampuan seorang guru dalam melaksanakan kewajiban-kewajibannya secara bertanggung jawab dan layak. Dengan demikian, kompetensi guru dapat didefinisikan sebagai penguasaan terhadap pengetahuan, keterampilan, nilai dan sikap yang direfleksikan dalam kebiasaan berpikir dan bertindak dalam menjalankan profesi sebagai guru (Syah, 2000).

\section{Beban Kerja Guru}

Menurut Tarwaka (2004:95), setiap pekerjaan merupakan beban bagi yang bersangkutan, beban tersebut dapat berupa beban fisik maupun mental. Sunarso (2010) menjelaskan bahwa beban berarti tanggungan yang harus dikerjakan sebagai tanggungan yang menjadi tanggung jawabnya. Sedangkan kerja adalah kegiatan melakukan sesuatu yang dilakukan bertujuan mendapatkan hasil pekerjaan (Sunarso dan Kusdi, 2010). Di sisi lain, Winarsunu (2008:84) mengemukakan bahwa beban kerja adalah kombinasi dari beban kerja kuantitatif dan kualitatif. Beban kerja secara kuantitatif yaitu timbul karena tugastugas terlalu banyak atau sedikit. Sedangkan beban kerja kualitatif, jika pekerja merasa tidak mampu melaksanakan tugas atau tugas tidak 
menggunakan keterampilan atau potensi dari pekerja. Dengan demikian, beban kerja guru adalah sekumpulan kegiatan yang menjadi tanggung jawab guru baik fisik maupun mental, secara kuantitatif maupun kualitatif yang harus diselesaikan dalam kurun waktu tertentu.

\section{Dukungan Sosial}

Menurut Dimatteo (1991), dukungan sosial adalah dukungan atau bantuan yang berasal dari orang lain seperti teman, keluarga, tetangga, rekan kerja dan orang lain. Sarason \& Pierce (dalam Baron \& Byrne, 2000) mendefinisikan dukungan sosial sebagai kenyamanan fisik dan psikologis yang diberikan oleh teman-teman dan anggota keluarga. Dukungan sosial adalah pertukaran bantuan antara dua individu yang berperan sebagai pemberi dan penerima (Shumaker \& Browne dalam Duffy \& Wong, 2003). Dengan demikian, dukungan sosial bagi guru dalam publikasi ilmiah adalah kenyamanan fisik dan psikologis, perhatian, penghargaan, dan bantuan bentuk lainnya yang diterima oleh guru dalam kegiatan publikasi ilmiah.

\section{METODE PENELITIAN}

Penelitian ini mengambil lokasi di SMP Negeri 1 Rembang dan SMP Negeri 3 Pengadegan Kabupaten Purbalingga. Teknik sampling yang digunakan dalam penelitian ini adalah sampling jenuh atau sensus dimana semua anggota populasi dijadikan sampel. Metode Penelitian yang digunakan dalam penelitian ini adalah metode penelitian kuantitatif format deskriptif studi kasus, yang tidak memiliki ciri-ciri pemairan (menyebar di permukaan), tetapi memusatkan diri pada suatu unit tertentu dari berbagai variabel. Teknik pengambilan data penelitian ini menggunakan kuesioner (angket), teknik observasi, wawancara dan dokumentasi. Pada penelitian ini, menggunakan sumber data primer dan sekunder untuk mendapatkan data yang lengkap. Teknik analisis data yang digunakan adalah korelasi product moment, regresi linier sederhana, dan regresi linier berganda. Validitas data yang dipakai adalah analisis butir soal sedangkan reliabilitas data adalah teknik Alpha Cronbrach.

\section{HASIL DAN PEMBAHASAN}


Produktivitas publikasi ilmiah guru belum menunjukkan perkembangan yang berarti khususnya di SMP Negeri 1 Rembang dan SMP Negeri 3 Pengadegan Kabupaten Purbalingga karena banyak faktor yang mempengaruhinya. Faktor-faktor tersebut antara lain motivasi guru, kompetensi guru, beban kerja guru dan dukungan sosial.

\section{Motivasi Guru}

Motivasi adalah proses yang menjelaskan intensitas, arah dan ketekunan individu untuk mencapai tujuannya (Mitchell, 1997). Dengan demikian, motivasi guru dalam kegiatan publikasi ilmiah berarti proses yang menjelaskan intensitas, arah dan ketekunan seorang guru dalam mencapai tujuannya yaitu produktivitas publikasi ilmiah yang tinggi.

Hasil penelitian menunjukkan bahwa penilaian responden terhadap motivasi guru dalam kegiatan publikasi ilmiah guru adalah rendah. Hal ini dapat dipahami karena minat guru untuk melaksanakan kegiatan publikasi ilmiah juga rendah. Hal ini dapat dilihat dari penilaian responden yang sebagian besar menggambarkan bahwa mereka tidak mempunyai kesadaran yang tinggi akan pentingnya kegiatan publikasi ilmiah. Selain itu, juga dikarenakan adanya anggapan bahwa kegiatan publikasi ilmiah hanya membebani guru untuk lebih memikirkan bagaimana membuat publikasi ilmiah sehingga mengabaikan tugas pokok guru yang sudah menyita waktu banyak juga. Hal itu sebagaimana yang diungkapkan oleh seorang responden sebagai berikut:

"Saya tidak setuju dengan kegiatan publikasi ilmiah, seharusnya guru lebih memikirkan bagaimana cara pengajaran yang baik, inovatif dan kreatif, bukan berkutat pada publikasi ilmiah yang semata-mata tuntutan kenaikan pangkat dan golongan. Pada akhirnya tupoksi guru menjadi berubah sebagai pemburu/penulis bukan pengajar."

Dari penilaian responden juga dapat diketahui bahwa sebagian besar guru enggan melaksanakan kegiatan publikasi ilmiah dikarenakan masih minimnya penghargaan materi maupun non materi dari pimpinan/kepala sekolah kepada guru yang melaksanakan kegiatan publikasi ilmiah. Hal tersebut sejalan dengan apa yang disampaikan oleh salah satu responden sebagai berikut:

"Sesungguhnya publikasi ilmiah itu bagus...tapi pelaksanaannya yang sulit...karena harus membagi waktu, tenaga dan pikiran antara tugas pokok, tugas 
tambahan, keluarga dan publikasi ilmiah serta lainnya...sementara penghargaan dari kepala sekolah masih kurang."

Oleh karenanya, faktor motivasi guru secara mandiri mampu mempengaruhi produktivitas publikasi ilmiah guru di SMP Negeri 1 Rembang dan SMP Negeri 3 Pengadegan Kabupaten Purbalingga.

Kesimpulan ini sejalan dengan pendapat Sinungan (2005) yang menjelaskan bahwa salah satu faktor yang mempengaruhi produktivitas adalah motivasi. Selain itu, dalam publikasi ilmiah sebagaimana dijelaskan Bambang (2005) guru perlu memiliki motivasi yang tinggi karena motivasi merupakan pengaruh dari dalam diri penulis untuk mendorong diri untuk senantiasa menghasilkan karya tulis.

Di sisi lain, hasil penelitian ini juga mendukung penelitian Noorjannah (2014) yang menjelaskan bahwa motivasi mempengaruhi rendahnya produktivitas publikasi ilmiah guru. Hal ini menunjukkan bahwa dalam rangka meningkatkan produktivitas publikasi ilmiah guru tidak mungkin mengabaikan faktor motivasi guru, karena motivasi yang tinggi menjadikan seorang guru bersemangat untuk melaksanakan publikasi ilmiah. Hasil penelitian ini juga mendukung hasil penelitian yang dilaksanakan oleh Jaedun (2011), Sukarno dan Larasati (2014) yang menunjukkan bahwa motivasi berpengaruh terhadap produktivitas publikasi ilmiah guru.

Hasil penelitian ini juga menunjukkan bahwa dari keempat faktor yang mempengaruhi produktivitas publikasi ilmiah guru, faktor motivasi guru mempunyai pengaruh yang paling kuat dan signifikan terhadap produktivitas publikasi ilmiah guru di SMP Negeri 1 Rembang dan SMP Negeri 3 Pengadegan Kabupaten Purbalingga.

Faktor motivasi guru menjadi faktor yang paling berpengaruh terhadap produktivitas publikasi ilmiah guru dikarenakan motivasi merupakan kondisi yang dapat membangkitkan, mengarahkan dan memelihara perilaku seorang guru untuk melakukan publikasi ilmiah.

Selain itu, motivasi juga merupakan hal yang sangat penting karena motivasilah yang menyebabkan, menyalurkan dan mendukung perilaku guru, supaya mau bekerja giat dan antusias mencapai hasil yang optimal dalam 
melaksanakan publikasi ilmiah. Hal ini sejalan dengan pendapat Dimyati dan Mudjiono (2001) yang menjelaskan bahwa sesuai dengan teori atribusi, persepsi individu terhadap penyebab perilakunya mempengaruhi cara kerjanya di masa depan.

Di sisi lain, dari hasil penelitian ini dapat diketahui juga bahwa koefisien determinasi ( $\mathrm{R}$ Square) sebesar 0,486. Hal ini berarti faktor motivasi guru hanya dapat menjelaskan perubahan faktor produktivitas publikasi ilmiah guru sebesar 48,6\% sementara 51,4\% dipengaruhi variabel lain di luar variabel motivasi guru.

\section{Kompetensi Guru}

Hasil penelitian menunjukkan bahwa penilaian responden terhadap kompetensi guru dalam melaksanakan kegiatan publikasi ilmiah adalah sedang. Hal ini dapat disebabkan karena sebagian besar guru di SMP Negeri 1 Rembang dan SMP Negeri 3 Pengadegan Kabupaten Purbalingga mengalami kesulitan terutama ide penulisan dan teknik penulisan. Hal itu seperti yang diungkapkan oleh seorang responden yang mengatakan sebagai berikut:

"Menurut saya, kesulitan terbesar yang saya alami dalam kegiatan publikasi ilmiah adalah ide penulisan dan teknik penulisan yang baik dan benar. Hal tersebut dikarenakan kurang adanya pembimbingan dari pihak yang berkompeten, selain itu juga kadang ada perbedaan pandangan dari masing-masing tim penilai...jadi saya bingung...mana yang akan saya ikuti."

Hasil penelitian ini juga menunjukkan bahwa faktor kompetensi guru secara mandiri mampu mempengaruhi produktivitas publikasi ilmiah guru di SMP Negeri 1 Rembang dan SMP Negeri 3 Pengadegan Kabupaten Purbalingga. Kesimpulan ini sejalan dengan pendapat Nugroho (2011) yang menjelaskan bahwa produktivitas publikasi ilmiah guru salah satunya ditentukan oleh faktor kompetensi guru dalam kegiatan publikasi ilmiah. Selain itu, Hasil penelitian ini juga mendukung penelitian Sujianto (2012) yang menjelaskan bahwa kompetensi guru mempengaruhi rendahnya produktivitas publikasi ilmiah guru.

Hal ini menunjukkan bahwa dalam rangka meningkatkan publikasi ilmiah guru harus mengindahan faktor kompetensi guru, karena kompetensi yang tinggi dalam membuat publikasi ilmiah menjadikan seorang guru bersemangat 
untuk melaksanakan publikasi ilmiah. Di sisi lain, kompetensi juga menunjukkan kapasitas seseorang dalam menyelesaikan tugas-tugas yang dipikulnya, sebagaimana Robbins (2003) menyebut kompetensi sebagai ability, yaitu kapasitas seseorang individu untuk mengerjakan berbagai tugas dalam suatu pekerjaan. Hasil penelitian ini juga mendukung hasil penelitian yang dilaksanakan oleh Chairunnisa (2014) dan Noorjannah (2014) yang menunjukkan bahwa kompetensi guru berpengaruh terhadap produktivitas publikasi ilmiah guru.

Faktor kompetensi guru juga memiliki pengaruh yang signifikan dengan arah positif terhadap produktivitas publikasi ilmiah guru PNS di SMP Negeri 1 Rembang dan SMP Negeri 3 Pengadegan Kabupaten Purbalingga. Meskipun kekuatan pengaruhnya berada di bawah faktor motivasi guru, kompetensi guru juga menjadi faktor yang tidak kalah penting guna meningkatkan produktivitas publikasi ilmiah guru. Hal ini dikarenakan kompetensi merupakan modal utama seorang guru untuk melakukan berbagai aktivitas termasuk publikasi ilmiah.

Selain itu, tanpa kompetensi mustahil seorang guru dapat melaksanakan tugas dengan sebaik baiknya. Hal tersebut sesuai dengan pendapat Ahsan yang menjelaskan bahwa kompetensi merupakan pengetahuan, keterampilan dan kemampuan yang dikuasai oleh seseorang yang telah menjadi bagian dari dirinya sehingga ia dapat melakukan perilaku-perilaku kognitif, afektif, dan psikomotorik dengan sebaik-baiknya (Mulyasa, 2012). Sementara itu, kompetensi guru yang diperlukan dalam kegiatan publikasi ilmiah khususnya dalam penulisan karya ilmiah antara lain motivasi dan disiplin yang tinggi, kemampuan mengolah data, kemampuan berpikir logis dan terpadu, kemampuan berbahasa (Bambang, 2005).

Dari hasil penelitian ini juga dapat diketahui bahwa koefisien determinasi (R Square) sebesar 0,339. Hal ini berarti faktor kompetensi guru hanya dapat menjelaskan perubahan faktor produktivitas publikasi ilmiah guru sebesar $33,9 \%$ sementara $66,1 \%$ dipengaruhi variabel lain di luar variabel kompetensi guru. 


\section{Beban Kerja Guru}

Pada penelitian ini, menunjukkan bahwa hasil deskripsi penilaian responden terhadap beban kerja guru kategorinya sedang. Artinya, beban kerja guru di SMP Negeri 1 Rembang dan SMP Negeri 3 Pengadegan sebagian besar cukup berat. Berdasarkan observasi, hal itu dikarenakan tugas yang harus ditanggung oleh setiap guru meliputi tugas pokok dan tugas tambahan. Tugas pokok untuk masing-masing guru sama yang membedakan adalah tugas tambahan yang diperolehnya. Hal itu sebagaimana yang diungkapkan oleh seorang responden sebagai berikut:

"Intinya, kegiatan publikasi ilmiah sangat menyita waktu...di sekolah sudah mengajar dan tugas tambahan sebagai wakil kepala sekolah bidang kesiswaan...kalau di rumah ya waktu untuk keluarga...apalagi kita sudah dibebankan dengan kurang lebih 40 jam kerja."

Selain melaksanakan tugas pokok berupa menyusun perencanaan, pelaksanaan dan penilaian serta bimbingan, guru juga harus mengadministrasikan setiap tugas yang dilaksanakan tersebut, belum lagi ditambah dengan tugas tambahan. Selain itu, SMP Negeri 1 Rembang sebagai sekolah senter di Purbalingga bagian timur, memiliki tambahan tugas yang cukup banyak. Oleh karenanya, beban kerja guru di lokasi ini cukup berat.

Hasil penelitian juga menunjukkan bahwa variabel beban kerja guru secara mandiri mampu mempengaruhi variabel produktivitas publikasi ilmiah guru di SMP Negeri 1 Rembang dan SMP Negeri 3 Pengadegan Kabupaten Purbalingga.

Hasil penelitian ini sesuai dengan pendapat Nugroho (2011) yang menjelaskan bahwa beban kerja guru yang padat menyebabkan tidak tersedianya waktu yang cukup untuk melaksanakan publikasi ilmiah. Oleh karenanya, beban kerja guru mempengaruhi produktivitas publikasi ilmiah guru. Hal ini menunjukkan bahwa dalam rangka meningkatkan produktivitas publikasi ilmiah guru harus memperhatikan faktor beban kerja guru, karena beban kerja guru dapat mempengaruhi produktivitas publikasi ilmiah yang dilaksanakan guru itu sendiri. 
Oleh karena beban kerja guru sangat padat baik secara kuantitatif maupun kualitatif yang harus diselesaikan dalam kurun waktu tertentu, tentu saja hal itu sangat menyita waktu, tenaga dan pikiran guru yang pada akhirnya akan mempengaruhi produktivitas publikasi ilmiah guru yang juga menjadi bagian tanggung jawabnya.

Hasil penelitian ini juga mendukung hasil penelitian yang dilaksanakan oleh Larasati (2014), Fitriah (2012), Sukarno dan Noorjannah (2014) yang menunjukkan bahwa beban kerja guru berpengaruh terhadap produktivitas publikasi ilmiah guru.

Faktor beban kerja guru berdasarkan hasil uji regresi linier sederhana (secara mandiri) terbukti berpengaruh signifikan terhadap produktivitas publikasi ilmiah guru dengan arah positif, namun berdasarkan hasil uji regresi linier berganda (secara simultan) terbukti berpengaruh signifikan terhadap produktivitas publikasi ilmiah guru dengan arah negatif.

Hasil penelitian yang demikian menunjukkan bahwa jika beban kerja guru (secara mandiri) meningkat maka produktivitas publikasi ilmiah guru juga meningkat. Hal ini dapat dipahami bahwa semakin banyak pekerjaan yang dipikul seseorang maka akan semakin banyak kegiatan yang diselesaikan karena orang tersebut beranggapan bahwa waktu begitu berharga sehingga tidak mau ada sedikit waktu luang yang sia-sia tanpa makna. Namun demikian, jika faktor motivasi guru, kompetensi guru, beban kerja guru dan dukungan sosial secara bersama-sama mempengaruhi produktivitas publikasi ilmiah guru maka faktor beban kerja guru berpengaruh negatif yang berarti jika beban kerja guru meningkat maka produktivitas publikasi ilmiah guru akan menurun. Dapat dikatakan juga bahwa beban kerja guru justru menjadi penghambat bagi poduktivitas publikasi ilmiah guru sementara ketiga faktor lainnya yaitu motivasi guru, kompetensi guru, dan dukungan sosial menjadi pendorong produktivitas publikasi ilmiah guru.

Meskipun memiliki pengaruh yang paling lemah terhadap produktivitas publikasi ilmiah guru, faktor beban kerja guru juga tidak bisa 
dipandang sebelah mata. Hal itu dikarenakan beban kerja menjadi sesuatu yang sangat membebani guru di mana sekumpulan kegiatan baik fisik maupun mental, secara kuantitatif maupun kualitatif harus diselesaikan dalam kurun waktu tertentu.

Penjelasan tersebut sejalan dengan Everly dan Girdano yang menyatakan bahwa beban kerja adalah keadaan dimana pekerja dihadapkan pada tugas yang harus diselesaikan pada waktu tertentu (Munandar, 2001). Oleh karenanya, semakin berat beban kerja seorang guru semakin sedikit waktu luang yang dimiliki olehnya, sehingga semakin sedikit juga waktu untuk melaksanakan publikasi ilmiah.

Dari hasil penelitian ini juga dapat diketahui bahwa koefisien determinasi ( $\mathrm{R}$ Square) sebesar 0,284. Hal ini berarti faktor beban kerja guru hanya dapat menjelaskan perubahan faktor produktivitas publikasi ilmiah guru sebesar $28,4 \%$ sementara $71,6 \%$ dipengaruhi variabel lain di luar variabel beban kerja guru.

\section{Dukungan Sosial}

Berdasarkan deskripsi penilaian responden terhadap faktor dukungan sosial, dapat diketahui kategorinya rendah. Hal ini menunjukkan bahwa dukungan sosial yang diperoleh guru dalam kegiatan publikasi ilmiah adalah rendah. Sebagian besar guru dalam penelitian ini kurang mendapat dukungan terutama dari kelompok yang meliputi dukungan Forum MGMP dan keluarga. Artinya, tidak semua Forum MGMP membantu anggotanya untuk melaksanakan kegiatan publikasi ilmiah, hanya sebagian kecil Forum MGMP yang mendukung sepenuhnya kegiatan publikasi ilmiah anggotanya mulai dari mengadakan workshop, pembimbingan sampai pada tahap publikasi. Selain itu, dukungan keluarga yang diperoleh guru juga rendah karena sebagian besar keluarga guru menganggap sudah terlalu banyak waktu yang tersita untuk kegiatan sekolah sementara keluarga juga membutuhkan kebersamaan dan perhatian. Hal itu seperti yang diungkapkan oleh salah satu responden yang berikut:

"Saya tidak mendapat dukungan dari keluarga terutama istri saya dalam kegiatan publikasi ilmiah... malah istri saya cemberut...kebanyakan pekerjaan katanya." 
Hasil penelitian ini juga menunjukkan bahwa faktor dukungan sosial berpengaruh positif dan signifikan terhadap produktivitas publikasi ilmiah guru di SMP Negeri 1 Rembang dan SMP Negeri 3 Pengadegan Kabupaten Purbalingga.

Hal tersebut sesuai dengan pendapat Sinungan (2005) yang mengungkapkan bahwa salah satu faktor yang mempengaruhi produktivitas adalah dukungan sosial. Dukungan sosial sendiri adalah kenyamanan, perhatian, penghargaan, maupun bantuan dalam bentuk lainnya yang diterima individu dari orang lain ataupun dari kelompok (Sarafino, 2002). Hal ini tidak terlepas dari kodrat manusia sebagai mahluk sosial yang senantiasa membutuhkan bantuan orang lain dalam menyelesaikan tugas-tugasnya. Begitu juga dalam kegiatan publikasi ilmiah, seorang guru pasti sangat membutuhkan dukungan dari pihak lain baik yang bersifat fisik maupun non fisik guna meningkatkan produktivitasnya.

Hasil penelitian ini sejalan dengan hasil penelitian Murni (2015) yang menjelaskan bahwa dukungan sosial mempengaruhi produktivitas publikasi ilmiah guru. Hal ini juga berarti bahwa dalam rangka meningkatkan produktivitas publikasi ilmiah guru harus memperhatikan faktor dukungan sosial, karena dukungan sosial yang tinggi dapat mempengaruhi produktivitas publikasi ilmiah. Hasil penelitian ini juga mendukung hasil penelitian yang dilaksanakan oleh Sukarno (2014) dan Sujianto (2012) juga penelitian oleh Nurkholis dan Yovita yang menunjukkan bahwa dukungan sosial berpengaruh terhadap produktivitas publikasi ilmiah guru.

Faktor dukungan sosial memiliki pengaruh yang signifikan dengan arah positif terhadap produktivitas publikasi ilmiah guru PNS di SMP Negeri 1 Rembang dan SMP Negeri 3 Pengadegan Kabupaten Purbalingga. Meskipun bukan faktor yang paling kuat pengaruhnya, dukungan sosial menjadi hal yang tidak bisa diabaikan begitu saja. Hal ini dikarenakan sebagai mahluk sosial, guru juga tidak bisa lepas dari bantuan pihak lain di luar dirinya dalam rangka memenuhi segala kebutuhannya.

Hal tersebut sebagaimana pendapat Dimatteo (1991), yang menjelaskan bahwa dukungan sosial merupakan dukungan atau bantuan yang 
berasal dari orang lain seperti teman, keluarga, tetangga, rekan kerja dan orang lain. Begitu juga dalam kegiatan publikasi ilmiah, guru pasti sangat membutuhkan dukungan baik dari teman sejawat, pimpinan, keluarga maupun fasilitas penunjang lainnya.

Dari hasil penelitian ini juga dapat diketahui bahwa koefisien determinasi (R Square) sebesar 0,343. Hal ini berarti faktor dukungan sosial hanya dapat menjelaskan perubahan faktor produktivitas publikasi ilmiah guru sebesar $34,3 \%$ sementara $65,7 \%$ dipengaruhi variabel lain di luar variabel beban kerja guru.

Di sisi lain, faktor motivasi guru, kompetensi guru, beban kerja guru dan dukungan sosial secara simultan memiliki nilai $\mathrm{R}$ square (koefisien determinasi) sebesar 0,531. Artinya 53,1\% variasi produktivitas publikasi ilmiah guru dapat dijelaskan oleh variasi dari faktor motivasi guru, kompetensi guru, beban kerja guru dan dukungan sosial secara simultan. Sedangkan yang 46,9\% disebabkan oleh variabel lainnya di luar penelitian ini.

\section{PENUTUP}

\section{SIMPULAN}

a. Semakin tinggi motivasi guru maka semakin tinggi pula produktivitas publikasi ilmiah guru PNS di SMP Negeri 1 Rembang dan SMP Negeri 3 Pengadegan Kabupaten Purbalingga. Selain itu, faktor motivasi guru juga merupakan faktor yang paling kuat pengaruhnya (sebesar 48,6\%) terhadap produktivitas publikasi ilmiah guru, sedangkan kekuatan pengaruh yang sebesar 51,4\% ditentukan oleh faktor lain di luar faktor motivasi guru.

b. Semakin tinggi kompetensi guru maka semakin tinggi pula produktivitas publikasi ilmiah guru PNS di SMP Negeri 1 Rembang dan SMP Negeri 3 Pengadegan Kabupaten Purbalingga. Kekuatan pengaruh faktor kompetensi guru masih di bawah kekuatan pengaruh motivasi guru yaitu 
$33,9 \%$ sementara $66,1 \%$ dipengaruhi faktor lain di luar faktor kompetensi guru.

c. Secara mandiri, semakin tinggi beban kerja guru maka semakin tinggi pula produktivitas publikasi ilmiah guru, sedangkan secara bersama-sama dengan faktor lain, semakin tinggi beban kerja guru maka semakin rendah produktivitas publikasi ilmiah guru PNS di SMP Negeri 1 Rembang dan SMP Negeri 3 Pengadegan Kabupaten Purbalingga. Oleh karena itu, faktor beban kerja guru bisa menjadi faktor pendorong maupun penghambat produktivitas publikasi ilmiah guru. Selain itu, faktor beban kerja guru mempunyai pengaruh yang paling lemah diantara ketiga faktor lainnya. Hal ini dikarenakan faktor beban kerja guru hanya dapat menjelaskan perubahan faktor produktivitas publikasi ilmiah guru sebesar 28,4\% sementara sebesar 71,6\% dipengaruhi faktor lain di luar faktor beban kerja guru.

d. Semakin tinggi dukungan sosial maka semakin tinggi pula produktivitas publikasi ilmiah guru PNS di SMP Negeri 1 Rembang dan SMP Negeri 3 Pengadegan Kabupaten Purbalingga. Faktor dukungan sosial hanya dapat menjelaskan perubahan faktor produktivitas publikasi ilmiah guru sebesar $34,3 \%$ sementara $65,7 \%$ dipengaruhi faktor lain di luar faktor beban kerja guru.

e. Faktor Motivasi Guru, Kompetensi Guru, dan Dukungan Sosial secara simultan terbukti secara signifikan berpengaruh sebesar $53,1 \%$ terhadap Produktivitas Publikasi Ilmiah Guru PNS di SMP Negeri 1 Rembang dan SMP Negeri 3 Pengadegan Kabupaten Purbalingga, sedangkan yang sebesar 46,9\% disebabkan oleh variabel lainnya di luar penelitian ini.

f. Faktor pendorong produktivitas publikasi ilmiah guru PNS di SMP Negeri 1 Rembang dan SMP Negeri 3 Pengadegan Kabupaten Purbalingga antara lain motivasi guru, kompetensi guru, dan dukungan sosial, sedangkan faktor penghambatnya adalah beban kerja guru.

\section{Saran}

a. Sangat penting untuk mengoptimalkan faktor motivasi guru guna meningkatkan produktivitas publikasi ilmiah guru. Hal itu dapat dilakukan 
dengan cara membangkitkan kesadaran kepada para guru akan pentingnya publikasi ilmiah bagi dunia pendidikan khususnya dan masyarakat pada umumnya, memberikan penghargaan yang setinggi-tingginya kepada para guru yang melaksanakan publikasi ilmiah baik berupa materi maupun non materi, memfasilitasi para guru yang akan melaksanakan publikasi ilmiah dengan baik.

b. Sangat penting bagi pihak-pihak terkait untuk menyelenggarakan pelatihan publikasi ilmiah guru yang intensif, menyelenggarakan pembimbingan dalam pelaksanaan publikasi ilmiah dari pihak yang berkompeten dalam rangka meningkatkan kompetensi guru untuk melaksanakan publikasi ilmiah.

c. Penting dilakukan untuk mengurangi beban kerja guru dengan tugas-tugas tambahan yang kurang mendukung tugas pokoknya, memberikan fasilitas asistensi untuk guru, bisa dari pihak staf Tata Usaha guna membantu tugas guru terutama yang berhubungan tugas administrasi maupun yang bersifat teknis.

d. Sangat penting untuk menciptakan budaya kerja sama antar teman sejawat, meningkatkan dukungan dari pimpinan bisa berupa memberikan penghargaan yang tinggi baik materi maupun non materi kepada guru yang melaksanakan publikasi ilmiah, sekolah menyediakan fasilitas-fasilitas pendukung dalam kegiatan publikasi ilmiah seperti buku referensi, jaringan internet, perangkat TIK dan lain-lain. Selain itu, juga perlu memberdayakan Forum MGMP tiap-tiap mata pelajaran guna membantu guru dalam melaksanakan kegiatan publikasi ilmiah.

e. Faktor motivasi guru, kompetensi guru, beban kerja guru dan dukungan sosial secara simultan mempunyai pengaruh yang signifikan 53,1\% terhadap produktivitas publikasi ilmiah guru di SMP Negeri 1 Rembang dan SMP Negeri 3 Pengadegan Kabupaten Purbalingga. Artinya, sebesar 46,9\% produktivitas publikasi ilmiah dipengaruhi oleh faktor lain di luar penelitian ini. Oleh karenanya, sangat perlu diadakan penelitian lebih lanjut dari variabel-variabel ini. 


\section{DAFTAR PUSTAKA}

Baron \& Byrne. (2000). Social Psychology 9th Ed. Massachusetts: Pearson Education Company

Kusnendi, 2009, Metode Penelitian Aplikasi Statistika, Hand Out, Program Studi Magister Pendidikan IPS Sekolah Pascasarjana UPI, Bandung.

Mitchell, TR, 1997, Research in Organizational Behavior, Greenwich, CT: JAI Press, hal 60-62.

Mulyasa, 2012, Standar Kompetensi dan Sertifikasi Guru, PT. Remaja Rosdakarya, Bandung.

Nugroho, Hery (2011), Cara Mudah Menjadi Guru Penulis, Dahara Prize, Semarang

Robin, Stephen; Judge, Timothy A., 2008, Perilaku Organisasi, Salemba Empat, Jakarta, hal 229-239.

Sarafino, E.P . (1994). Health Psychology: Biopsychosocial Interaction (4th ed.). New York: John Wiley and Sons.

Sinungan, Muchdarsyah, 2005, Produktivitas: Apa dan Bagaimana, Edisi Kedua, Bumi Aksara

Syah, Muhibbin, 2008, Psikologi Pendidikan dengan Pendekatan Baru, Remaja Rosdakarya, Bandung.

Chairunnisa, Connie, 2016, "Pemberdayaan Guru melalui Pelatihan Penulisan Karya Ilmiah di Sekolah Menegah Kejuruan", Faktor Jurnal Kependidikan, Volume 3 No. 2 Juli 2016. (journal.lppmunida.ac.id).

Jaedun, Amad 2011, Pengembangan Profesionalisme Guru melalui Penulisan Karya Tulis Ilmiah, Makalah Seminar KTI dan PTK di SMK Negeri 1 Sedayu, Bantul, Togyakarta.

Kementerian Pendidikan Nasional, Direktorat Jenderal Peningkatan Mutu Pendidik dan Tenaga Kependidikan, 2010, Pembinaan dan Pengembangan Profesi Guru Buku 1 Pedoman Pengelolaan Pengembangan Keprofesian Berkelanjutan (PKB), Jakarta.

Larasati, Rahma Titi, 2014, "Faktor-Faktor Penghambat Penulisan Karya Tulis Ilmiah Dalam Pengembangan Keprofesian Berkelanjutan Guru SD N Lempuyangwangi Yogyakarta”, UNY (eprints.uny.ac.id).

Ludiana, Fitriah, 2012, "Hambatan Guru Sekolah Dasar dalam Menulis Karya Tulis Ilmiah di Kecamatan Kebasen Kabupaten Banyumas”, UNY, Skripsi. 
Noorjannah, Lilies, 2014, "Pengembangan Profesionalisme Guru Melalui Penulisan Karya Tulis Ilmiah Bagi Guru Profesional Di SMA Negeri 1 Kauman Kabupaten Tulungagung”.

Sukarno, "Kendala Dan Upaya Pengembangan Keprofesian Guru Sekolah Dasar Melalui Kegiatan Penulisan Karya Ilmiah”, Prosiding Seminar Nasional Inovasi Pendidikan Inovasi Pembelajaran Berbasis Karakter dalam Menghadapi Masyarakat Ekonomi ASEAN Universitas Sebelas Maret, Surakarta (jurnal.fkip.uns.ac.id).

Sujianto dkk, 2012, "Pengembangan Profesionalitas Berkelanjutan Guru Bersertifikat Pendidik Di SMK Rumpun Teknologi”, Jurnal Teknologi Dan Kejuruan, Vol. 35, No. 1, Pebruari 2012. 